\title{
KEMAMPUAN PEMECAHAN MASALAH DAN KOMUNIKASI MATEMATIS MENGGUNAKAN MODEL STAD BERBANTUAN ALAT PERAGA DI SMP ISLAM KARANGPLOSO
}

\author{
Ngganiyatur Rochmah $^{1}$, RR. Ettie Rukmigarsari ${ }^{2}$, Siti Nurul Hasana ${ }^{3}$ \\ ${ }^{1,2,3}$ Pendidikan matematika, Fakultas Keguruan dan Ilmu Pendidikan Universitas Islam Malang \\ Email: $\underline{\text { nggoniasylvania@gmail.com }}$
}

\begin{abstract}
Abstrak
Pembelajaran matematika merupakan proses interaksi atau komunikasi antara guru dan peserta didik serta lingkungan belajar agar peserta didik memperoleh kompetensi dalam bidang matematika. Kompetensi di bidang matematika yang harus dimiliki oleh peserta didik salah satunya adalah kemampuan pemecahan masalah matematis dan kemampuan komunikasi matematis, karena pada dasarnya kemampuan tersebut merupakan suatu kemampuan yang penting dan perlu dikuasai oleh peserta didik yang belajar matematika. Khususnya peserta didik sekolah menengah (SM). Tujuan dari penelitian ini adalah mengetahui adanya perbedaan kemampuan pemecahan masalah dan komunikasi matematis peserta didik yang menggunakan model STAD berbantuan alat peraga dengan model konvensional. Metode yang digunanakan dalam penelitian ini adalah mix method research, (metode campuran) dengan jenis sequential explanatory. Desain penelitian kuantitatif menggunakan true experimental. Sedangkan desain penelitian kualitatif menggunakan deskriptif-kualitatif yang digunakan untuk melengkapi penelitian kuantitatif. Hasil penelitian menunjukkan bahwa perlakuan dengan model kooperatif tipe STAD dapat mempengaruhi kemampuan pemecahan masalah matematis dan kemampuan komunikasi matematis peserta didik. Hal tersebut dapat dilihat dalam hasil analisis data kuantitatif maupun kualitatif yang menunjukkan adanya perbedaan kemampuan pemecahan masalah matematis dan kemampuan komunikasi matematis antara peserta didik kelas eksperimen yang diberi perlakuan dengan model kooperatif tipe STAD dengan peserta didik kelas kontrol yang diberi perlakuan dengan model konvensional.
\end{abstract}

Kata Kunci: model pembelajaran kooperatif tipe STAD, alat peraga, kemampuan pemecahan masalah matematis, kemampuan komunikasi matematis.

\begin{abstract}
Mathematical learning is a process of interaction or communication between teachers and students and the learning environment so that students gain competence in the field of mathematics. One of the competencies in the field of mathematics that must be possessed by students is mathematical problem solving skills and mathematical communication skills, because basically these abilities are an ability that is important and needs to be mastered by students who learn mathematics. Especially middle school students. The purpose of this study was to determine the differences in problem solving skills and mathematical communication of students using the STAD model assisted with teaching aids with conventional models. The method used in this research is a mix method with sequential explanatory methods. Quantitative research design uses true experimental. While the qualitative research design uses descriptive-qualitative research that is used to complement quantitative research. The results of the study showed that treatment with the cooperative type STAD model could affect mathematical problem solving abilities and mathematical communication skills of students. This can be seen in the results of quantitative and qualitative data analysis which shows a difference in mathematical problem solving abilities and mathematical communication skills between experimental class students who were treated with the cooperative type STAD model and control class students who were treated with conventional models.
\end{abstract}

Keywords: STAD type cooperative learning model, teaching aids, mathematical problem solving abilities, mathematical communication skills. 


\section{PENDAHULUAN}

Era perkembangan zaman yang semakin maju seperti saat ini memberikan tuntutan pada dunia pendidikan untuk melakukan perubahan-perubahan yang seimbang sehingga mampu mencapai tujuan pendidikan yang sesungguhnya. Salah satu faktor utama yang mendorong perubahan tersebut adalah perkembangan Ilmu Pengetahuan dan Teknologi (IPTEK). Menurut UU SPN No. 20 tahun 2003 pendidikan merupakan upaya dasar serta terstruktur guna menciptakan suasana belajar dan sistem pembelajaran supaya peserta didik lebih memaksimalkan pengembangan potensi dirinya. Pendidikan sangat erat kaitannya dengan proses pembelajaran baik di lingkungan sekolah ataupun di luar sekolah.

Setiap proses pembelajaran mempunyai tujuan berupa perubahan perilaku manusia. Permendiknas Nomor 22 Tahun 2006 menjelaskan bahwa tujuan pembelajaran matematika di Indonesia ialah; (1) Pemahaman siswa terhadap konsep matematika, mendeskripsikan keterkaitan antar konsep serta mengaplikasikan konsep/algoritma secara luwes, akurat, efisien dan tepat; (2) pola dan sifat dapat digunakan siswa dalam penalaran, membuat generalisasi dengan melakukan manipulasi matematika, menjelaskan gagasan serta pernyataan matematika; (3) kompetensi dalam memahami masalah, mengonsepkan model matematika, memecahkan model, serta menyelesaikan solusi yang diperoleh oleh siswa; (4) gagasan yang dapat dikomunikasikan siswa untuk memperjelas keadaan Atau masalah dalam simbol, tabel, diagram, atau media lain; (5) mempunyai kemauan untuk mengetahui sesuatu serta ketertarikan dalam mempelajari matematika, mempuyai sikap yang gigih dalam menjelaskan konsep serta menyelesaikan masalah sebagai bentuk sikap menghargai kegunaan matematika dalam kehidupan.

Beberapa kemampuan yang seharusnya dimiliki oleh peserta didik adalah kemampuan pemecahan masalah matematis. Pada dasarnya kemampuan pemecahan masalah matematis merupakan satu kompetensi yang penting dan harus dikuasai peserta didik dalam pembelajaran matematika. Hendriana (2017) mengemukakan bahwa pemecahan masalah matematis mencakup model, prosedur serta strategi yang merupakan proses inti dan utama dalam kurikulum matematika atau sasaran umum pembelajaran matematika, bahkan sebagai 'jantungnya' matematika. Tidak hanya kemampuan pemecahan masalah matematis, kemampuan komunikasi matematis juga suatu kompetensi dasar yang harus dikuasai oleh peserta didik sekolah jenjang menengah. Oleh karena itu, untuk meningkatkan kemampuankemampuan tersebut perlu adanya proses pembelajaran yang baik. Proses pembelajaran yang baik pastinya menggunakan model pembelajaran yang baik. Model pembelajaran adalah seluruh perencanaan dan prosedur maupun tahapan-tahapan aktivitas pembelajaran termasuk pemilihan strategi penilaian. Model pembelajaran juga merupakan rencana pembelajaran untuk mencapai tujuan pembelajaran dan dilaksanakan dengan suatu sintaks (Suyono dan Hariyanto, 2011). Salah satu model pembelajaran yang memfasilitasi peserta didik untuk memiliki kemampuan-kemampuan tersebut adalah model pembelajaran kooperatif tipe STAD. Model tersebut mengelompokkan peserta didik secara akademik, yang dikolaborasikan secara heterogen berdasarkan gender, ras, dan etnis.

\section{METODE}

Metode penelitian yang digunakan adalah mixed methods research. Cresswell (2016) menyatakan bahwa mixed methods research adalah metode dalam penelitian yang mengkombinasikan atau menggabungkan antara metode penelitian kuantitatif dan kualitatif. Strategi penelitian kombinasi yang digunakan dalam penelitian ini adalah sequential explanatory. Creswell (2016) menyatakan bahwa metode penelitian dengan strategi sequential explanatory diterapkan dengan pengumpulan dan analisis data kuantitatif pada tahap pertama kemudian diikuti pengumpulan dan analisis data data kualitatif pada tahap kedua. Penelitian kuantitatif menggunakan jenis penelitian eksperimen dengan metode true 
experimental dengan desain penelitian pretest posttest control group design. Sedangkan penelitian kualitatif yang digunakan adalah deskriptif-kualitatif, yaitu suatu prosedur penelitian yang menggambarkan atau mendeskripsikan kemampuan pemecahan masalah matematis dan kemampuan komunikasi matematis peserta didik berupa kata tertulis atau lisan dari subjek dan perilaku yang diamati. Subjek dalam penelitian ini adalah peserta didik di SMP Islam Karangploso yang diambil secara acak (cluster random sampling) sebanyak 46 peserta didik.

Pengumpulan data kuantitatif menggunakan tes kemampuan pemecahan masalah dan komunikasi matematis yang disesuaikan dengan indikator. Sedangkan pengumpulan data kualitatif menggunakan non tes yaitu wawancara, observasi, dan catatan lapangan. Teknik analisis data dalam penelitian kuantitatif menggunakan metode statistik parametrik independent sample t-test. Keseluruhan pengolahan data dilakukan dengan menggunakan perangkat lunak SPSS 23. Independent sample t-test digunakan untuk mengetahui perbedaan pengaruh perlakuan yaitu pembelajaran yang menggunakan model kooperatif tipe STAD berbantuan alat peraga terhadap kemampuan pemecahan masalah matematis dan kemampuan komunikasi matematis kelas eksperimen dan kelas kontrol. Pada penelitian kualitatif, Sugiyono (2014) menyatakan bahwa analisis data dalam penelitian kualitatif adalah proses mencari dan menyusun secara sistematis data yang diperoleh dari hasil wawancara dan bahan-bahan lain, sehingga dapat mudah dipahami dan hasilnya dapat dijelaskan kepada orang lain. Analisis data penelitian kualitatif dilakukan dengan tahapantahapan yaitu reduksi data, penyajian data, dan verifikasi yang mendeskripsikan kemampuan pemecahan masalah dan komunikasi matematis.

\section{HASIL}

Hasil analisis data penelitian kuantitatif menggunakan metode statistik parametrik independent sample t-test. Prasyarat dari independent sample t-test adalah uji normalitas karena skala data yang diperoleh berskala interval dan rasio. Uji normalitas dilakukan untuk mengetahui apakah data nilai pretest maupun posttest dari eksperimen dan kelas kontrol berdistribusi normal atau tidak. Uji normalitas dalam penelitian ini menggunakan ShapiroWilk, karena sampel yang diambil adalah sampel yang kecil. Output uji normalitas data dikatakan berdistribusi normal jika nilai Sig lebih besar dari taraf signifikansi $\alpha=0,05$ pada tabel Test of Normality kolom Shapiro-Wilk pada output SPSS 23. Apabila nilai Sig lebih besar dari taraf signifikansi maka data berdistribusi normal atau $\mathrm{H}_{0}$ diterima. Apabila nilai Sig lebih kecil dari taraf signifikansi maka data tidak berdistribusi normal atau $\mathrm{H}_{0}$ ditolak (Field, 2009). Hasil uji normalitas data kemampuan pemecahan masalah matematis dan kemampuan komunikasi matematis kelas eksperimen dan kelas kontrol menunjukkan bahwa keseluruhan data menunjukkan bahwa hasil pretest-posttest kemampuan pemecahan masalah dan komunikasi matematis di kelas eksperimen maupun kelas kontrol keseluruhan nilai $p$-value lebih dari 0,05, maka $\mathrm{H}_{0}$ diterima. Jadi dapat disimpulkan bahwa dapat disimpulkan bahwa seluruh data pretest-posttest kedua kelas berdistribusi normal.

Setelah data terbukti berdistribusi normal, maka dilanjutkan ke uji perbandingan data pretest yang bertujuan untuk mengetahui apakah kedua sampel memiliki kemampuan awal yang sama atau tidak. Hasil uji perbandingan data pretest antar kelas ini menggunakan uji $t$ sampel bebas (independent sample t test) (Field, 2009).

Berdasarkan hasil uji kesamaan kemampuan awal (pretest), diperoleh hasil bahwa keseluruhan nilai p-value diatas taraf signifikansi 0,05 . Hal ini berarti bahwa kemampuan pemecahan masalah dan komunikasi matematis kedua kelas sama sebelum diberi perlakuan. Dengan demikian, kelas yang digunakan dalam penelitian adalah homogen. 
Setelah mengetahui kemampuan awal peserta didik, kemudian dilajutkan ke tahap uji hipotesis untuk mengetahui apakah terdapat perbedaan kemampuan peserta didik setelah diberi perlakuan. Hasil uji perbandingan data posttest antar kelas ini juga menggunakan uji $t$ sampel bebas (independent sample t test). Hasil analisis ditunjukkan pada Tabel 1.

Tabel 1 Hasil Perbandingan Data Posttest

\begin{tabular}{lccccc}
\hline \multirow{2}{*}{ Variabel } & Kelas Eksperimen & Kelas Kontrol & \multirow{2}{*}{ thitung } & \multirow{2}{*}{ t tabel } & p-value \\
\cline { 2 - 3 } & $\boldsymbol{M e a n} \mathbf{S} \boldsymbol{D}$ & $\boldsymbol{M e a n} \mathbf{\boldsymbol { S } \boldsymbol { D }}$ & & & \\
\hline KPMM & $76,26 \pm 7,08$ & $60,52 \pm 10,74$ & 5,868 & 2,015 & 0,000 \\
\hline KKM & $80,91 \pm 5,85$ & $62,39 \pm 9,64$ & 7,880 & 2,015 & 0,000 \\
\hline Ken
\end{tabular}

Keterangan:jika $p$-value $<0,05$ berarti ada perbedaan yang bermakna,

dan jika $p$-value $>0,05$ berarti tidak ada perbedaan yang bermakna.

p-valeu artinya sama dengan sig 2 tailed.

Berdasarkan hasil uji hipotesis (posttest), diperoleh bahwa keseluruhan nilai $p$-value dibawah taraf signifikansi 0,05 . Hal ini berarti bahwa terdapat perbedaan yang signifikan dalam kemampuan pemecahan masalah dan komunikasi matematis antara kelas eksperimen dan kelas kontrol. Pada kelas eksperimen hasil mean pada tes kemampuan pemecahan masalah dan komunikasi matematis lebih tinggi dari kelas kontrol. Dengan demikian, dapat disimpulkan bahwa pemberian perlakuan di kelas eksperimen dapat mempengaruhi dan meningkatkan kemampuan pemecahan masalah dan komunikasi matematis daripada pemberian perlakuan di kelas kontrol.

Analisis data kualitatif menggunakan deskriptif kualitatif dengan teknik pengumpulan data menggunakan wawancara, observasi, dan catatan lapangan. Pengujian derajat kepercayaan (kredibilitas) data dilakukan dengan teknik triangulasi. Moleong (2016) triangulasi merupakan suatu teknik untuk memeriksa keabsahan data dengan memanfaatkan sesuatu yang lain di luar data itu untuk keperluan pengecekan atau sebagai pembanding terhadap data itu. Berikut hasil observasi kegiatan guru dan hasil observasi kegiatan peserta didik kelas eksperimen dilihat pada Tabel 2 dan Tabel 3.

Tabel 2 Hasil Observasi Kegiatan Guru Kelas Eksperimen

\begin{tabular}{|c|c|c|c|c|c|c|}
\hline \multirow{3}{*}{$\begin{array}{c}\text { Kegiatan Guru Kelas } \\
\text { Eksperimen }\end{array}$} & \multicolumn{3}{|c|}{ Pertemuan Pertama } & \multicolumn{3}{|c|}{ Pertemuan Kedua } \\
\hline & \multirow{2}{*}{$\begin{array}{l}\text { Nilai } \\
\text { Max }\end{array}$} & \multicolumn{2}{|c|}{ Nilai Pengamat } & \multirow{2}{*}{$\begin{array}{l}\text { Nilai } \\
\text { Max }\end{array}$} & \multicolumn{2}{|c|}{ Nilai Pengamat } \\
\hline & & 1 & 2 & & 1 & 2 \\
\hline Kegiatan Awal & 20 & 19 & 20 & 20 & 18 & 18 \\
\hline Kegiatan Inti & 60 & 55 & 56 & 60 & 56 & 58 \\
\hline Kegiatan Akhir & 10 & 10 & 10 & 10 & 10 & 10 \\
\hline Jumlah & 90 & 84 & 86 & 90 & 84 & 86 \\
\hline Presentase & $100 \%$ & $93,34 \%$ & $95 \%$ & $100 \%$ & $93,34 \%$ & $95 \%$ \\
\hline Taraf Keberhasilan & $\begin{array}{c}\text { Sangat } \\
\text { Baik }\end{array}$ & $\begin{array}{c}\text { Sangat } \\
\text { Baik }\end{array}$ & $\begin{array}{l}\text { Sangat } \\
\text { Baik }\end{array}$ & $\begin{array}{c}\text { Sangat } \\
\text { Baik }\end{array}$ & $\begin{array}{c}\text { Sangat } \\
\text { Baik }\end{array}$ & $\begin{array}{c}\text { Sangat } \\
\text { Baik }\end{array}$ \\
\hline Rata-rata & & & & & & \\
\hline
\end{tabular}

Tabel 3 Hasil Observasi Kegiatan Peserta Didik Kelas Eksperimen

\begin{tabular}{|c|c|c|c|c|c|c|}
\hline \multirow{3}{*}{$\begin{array}{l}\text { Kegiatan Peserta Didik } \\
\text { Kelas Eksperimen }\end{array}$} & \multicolumn{3}{|c|}{ Pertemuan Pertama } & \multicolumn{3}{|c|}{ Pertemuan Kedua } \\
\hline & \multirow{2}{*}{$\begin{array}{l}\text { Nilai } \\
\text { Max }\end{array}$} & \multicolumn{2}{|c|}{ Nilai Pengamat } & \multirow{2}{*}{$\begin{array}{l}\text { Nilai } \\
\text { Max }\end{array}$} & \multicolumn{2}{|c|}{ Nilai Pengamat } \\
\hline & & 1 & 2 & & 1 & 2 \\
\hline Kegiatan Awal & 20 & 19 & 20 & 20 & 19 & 20 \\
\hline Kegiatan Inti & 55 & 51 & 51 & 55 & 52 & 51 \\
\hline Kegiatan Akhir & 10 & 9 & 9 & 10 & 9 & 9 \\
\hline Jumlah & 85 & 79 & 80 & 85 & 80 & 80 \\
\hline Presentase & $100 \%$ & $92,94 \%$ & $94,12 \%$ & $100 \%$ & $94,12 \%$ & $94,12 \%$ \\
\hline Taraf Keberhasilan & $\begin{array}{c}\text { Sangat } \\
\text { Baik }\end{array}$ & $\begin{array}{c}\text { Sangat } \\
\text { Baik }\end{array}$ & $\begin{array}{c}\text { Sangat } \\
\text { Baik }\end{array}$ & $\begin{array}{c}\text { Sangat } \\
\text { Baik }\end{array}$ & $\begin{array}{c}\text { Sangat } \\
\text { Baik }\end{array}$ & $\begin{array}{c}\text { Sangat } \\
\text { Baik }\end{array}$ \\
\hline Rata-rata & & & & & & \\
\hline
\end{tabular}


Sedangkan hasil observasi kegiatan guru dan hasil observasi kegiatan peserta didik kelas eksperimen dilihat pada Tabel 4 dan Tabel 5.

Tabel 4 Hasil Observasi Kegiatan Guru Kelas Kontrol

\begin{tabular}{|c|c|c|c|c|c|c|}
\hline \multirow{3}{*}{$\begin{array}{l}\text { Kegiatan Guru } \\
\text { Kelas Kontrol }\end{array}$} & \multicolumn{3}{|c|}{ Pertemuan Pertama } & \multicolumn{3}{|c|}{ Pertemuan Kedua } \\
\hline & \multirow{2}{*}{ Nilai Max } & \multicolumn{2}{|c|}{ Nilai Pengamat } & \multirow{2}{*}{$\begin{array}{l}\text { Nilai } \\
\text { Max }\end{array}$} & \multicolumn{2}{|c|}{ Nilai Pengamat } \\
\hline & & 1 & 2 & & 1 & 2 \\
\hline Kegiatan Awal & 20 & 19 & 18 & 20 & 19 & 20 \\
\hline Kegiatan Inti & 60 & 57 & 56 & 60 & 57 & 56 \\
\hline Kegiatan Akhir & 10 & 9 & 10 & 10 & 9 & 10 \\
\hline Jumlah & 90 & 85 & 84 & 90 & 85 & 86 \\
\hline Presentase & $100 \%$ & $94 \%$ & $93,34 \%$ & $100 \%$ & $94 \%$ & $95 \%$ \\
\hline Taraf Keberhasilan & $\begin{array}{c}\text { Sangat } \\
\text { Baik }\end{array}$ & $\begin{array}{c}\text { Sangat } \\
\text { Baik }\end{array}$ & $\begin{array}{c}\text { Sangat } \\
\text { Baik }\end{array}$ & $\begin{array}{c}\text { Sangat } \\
\text { Baik }\end{array}$ & $\begin{array}{c}\text { Sangat } \\
\text { Baik }\end{array}$ & $\begin{array}{c}\text { Sangat } \\
\text { Baik }\end{array}$ \\
\hline
\end{tabular}

Tabel 5 Hasil Observasi Kegiatan Peserta Didik Kelas Kontrol

\begin{tabular}{|c|c|c|c|c|c|c|}
\hline \multirow{3}{*}{$\begin{array}{c}\text { Kegiatan Peserta Didik } \\
\text { Kelas Kontrol }\end{array}$} & \multicolumn{3}{|c|}{ Pertemuan Pertama } & \multicolumn{3}{|c|}{ Pertemuan Kedua } \\
\hline & \multirow{2}{*}{$\begin{array}{l}\text { Nilai } \\
\text { Max }\end{array}$} & \multicolumn{2}{|c|}{ Nilai Pengamat } & \multirow{2}{*}{$\begin{array}{l}\text { Nilai } \\
\text { Max }\end{array}$} & \multicolumn{2}{|c|}{ Nilai Pengamat } \\
\hline & & 1 & 2 & & 1 & 2 \\
\hline Kegiatan Awal & 20 & 18 & 20 & 20 & 19 & 20 \\
\hline Kegiatan Inti & 55 & 52 & 52 & 55 & 52 & 52 \\
\hline Kegiatan Akhir & 10 & 10 & 10 & 10 & 10 & 10 \\
\hline Jumlah & 85 & 80 & 82 & 85 & 81 & 82 \\
\hline Presentase & $100 \%$ & $94,12 \%$ & $96,47 \%$ & $100 \%$ & $95,29 \%$ & $96,47 \%$ \\
\hline Taraf Keberhasilan & $\begin{array}{c}\text { Sangat } \\
\text { Baik }\end{array}$ & $\begin{array}{c}\text { Sangat } \\
\text { Baik }\end{array}$ & $\begin{array}{c}\text { Sangat } \\
\text { Baik }\end{array}$ & $\begin{array}{c}\text { Sangat } \\
\text { Baik }\end{array}$ & $\begin{array}{c}\text { Sangat } \\
\text { Baik }\end{array}$ & $\begin{array}{c}\text { Sangat } \\
\text { Baik }\end{array}$ \\
\hline Rata-rata & & & & & & \\
\hline
\end{tabular}

Analisis data kualitatif menggunakan teknik pengumpulan data dengan catatan lapangan digunakan untuk mengamati perilaku peserta didik di dalam kelas yang tidak terdapat pada lembar observasi. Berikut hasil analisis catatan lapangan pada Tabel 6.

Tabel 6 Hasil Catatan Lapangan Kelas Eksperimen dan Kelas Kontrol

\begin{tabular}{|c|c|c|c|}
\hline \multicolumn{2}{|c|}{ Kelas Eksperimen } & \multicolumn{2}{|c|}{ Kelas Kontrol } \\
\hline Pengamat I & Pengamat II & Pengamat I & Pengamat II \\
\hline $\begin{array}{l}\text { (1) Peserta didik } \\
\text { mengikuti kegiatan } \\
\text { pembelajaran secara } \\
\text { aktif dan memberikan } \\
\text { tanggapan mengenai } \\
\text { materi; } \\
\text { (2) Peserta didik } \\
\text { mengikuti } \\
\text { pembelajaran dengan } \\
\text { serius namun ada } \\
\text { sebagian peserta didik } \\
\text { yang kurang serius } \\
\text { dan berdiskusi diluar } \\
\text { topik pembelajaran; } \\
\text { (3) Keadaan kelas } \\
\text { cukup kondusif; } \\
\text { (4) Waktu sedikit } \\
\text { kurang efisien. }\end{array}$ & $\begin{array}{l}\text { (1) Peserta didik } \\
\text { mengikuti kegiatan } \\
\text { pembelajaran dengan } \\
\text { baik; } \\
\text { (2) Peserta didik } \\
\text { mengikuti } \\
\text { pembelajaran dengan } \\
\text { serius dan antusias; } \\
\text { (3) Peserta didik } \\
\text { berdiskusi kelompok } \\
\text { dengan serius dalam } \\
\text { menyelesaikan } \\
\text { masalah; } \\
\text { (4) Keadaan kelas } \\
\text { kondusif; } \\
\text { (5) Waktu lebih } \\
\text { diperhatikan lagi. }\end{array}$ & $\begin{array}{l}\text { (1) Peserta didik aktif } \\
\text { bertanya dan aktif } \\
\text { menanggapi } \\
\text { pertanyaan dari guru; } \\
\text { (2) Keadaan kelas } \\
\text { cukup kondusif saat } \\
\text { mengerjakan soal } \\
\text { yang diberikan guru } \\
\text { meskipun terdapat } \\
\text { beberapa peserta didik } \\
\text { yang ramai; } \\
\text { (3) Penggunaan waktu } \\
\text { cukup efisien. } \\
\text { (4) Guru terlalu cepat } \\
\text { menyampaikan } \\
\text { materi. }\end{array}$ & $\begin{array}{l}\text { (1) Peserta didik } \\
\text { mengikuti kegiatan } \\
\text { pembelajaran dengan } \\
\text { baik; } \\
\text { (2) Peserta didik } \\
\text { serius dalam } \\
\text { mendengarkan dan } \\
\text { menanggapi } \\
\text { penjelasan guru atau } \\
\text { peserta didik lainnya; } \\
\text { (3) keadaan kelas } \\
\text { cukup tertib meskipun } \\
\text { etrdapat beberapa } \\
\text { peserta didik yang } \\
\text { ramai; } \\
\text { (4) Pengggunaan } \\
\text { waktu efisien. }\end{array}$ \\
\hline
\end{tabular}

Hasil analisis data wawancara yang dibandingkan dengan tes di kelas eksperimen telah memenuhi hampir keseluruhan indikator kemampuan pemecahan masalah dan 
komunikasi matematis. Sedangkan di kelas kontrol hanya memehuni beberapa indikator kemampuan pemecahan masalah dan komunikasi matematis. Berikut hasil analisis wawancara kelas eksperimen dan kelas kontrol ditunjukkan pada Tabel 7.

Tabel 7 Hasil Wawancara Peserta Didik Kelas Eksperimen dan Kelas Kontrol

\begin{tabular}{cll}
\hline Kategori & \multicolumn{1}{c}{ Kelas Eksperimen } & \multicolumn{1}{c}{ Kelas Kontrol } \\
\hline \multirow{2}{*}{ Tinggi } & $\begin{array}{l}\text { Memenuhi semua indikator kemampuan } \\
\text { pemecahan masalah matematis dan } \\
\text { kemampuan komunikasi matematis }\end{array}$ & $\begin{array}{l}\text { Memenuhi 3 dari 4 indikator kemampuan } \\
\text { pemecahan masalah matematis dan semua } \\
\text { indikator kemampuan komunikasi matematis }\end{array}$ \\
\hline \multirow{3}{*}{ Sedang } & $\begin{array}{l}\text { Memenuhi 3 dari 4 indikator kemampuan } \\
\text { pemecahan masalah matematis dan 2 dari 3 } \\
\text { indikator kemampuan komunikasi matematis. }\end{array}$ & $\begin{array}{l}\text { Memenuhi 2 dari 4 indikator kemampuan } \\
\text { pemecahan masalah matematis dan 2 dari 3 } \\
\text { indikator kemampuan komunikasi matematis }\end{array}$ \\
\hline \multirow{3}{*}{ Rendah } & $\begin{array}{l}\text { memenuhi 2 dari 4 indikator kemampuan } \\
\text { pemecahan masalah matematis dan 1 dari 3 } \\
\text { indikator kemampuan komunikasi matematis. }\end{array}$ & $\begin{array}{l}\text { Memenuhi 1 dari 4 indikator kemampuan } \\
\text { pemecahan masalah matematis dan 1 dari 3 } \\
\text { indikator kemampuan komunikasi matematis }\end{array}$ \\
\hline
\end{tabular}

\section{PEMBAHASAN}

Menurut Ismunamto (2011) matematika adalah pola pikir, pola mengorganisasikan pembuktian yang logis, ilmu tentang keteraturan pola, ide, bahasan yang memanfaatkan istilah yang didefinisikan dengan teliti, jelas, akuran, dan dipaparkan dalam bentuk simbol, pengetahuan tentang bentuk yang terstruktur, sifat-sifatnya dibuat secara deduktif berdasarkan sifat-sifat yang dapat dibuktikan kebenarannya, dan unsur-unsur yang didefinisikan dan tidak didefinisikan. Hudojo (2005) menyatakan bahwa pembelajaran matematika menurut pandangan konstruktivistik adalah pembelajaran yang membantu siswa untuk membangun konsep-konsep matematika dengan kemampuannya sendiri melalui proses internalisasi sehingga konsep tersebut terbangun sendiri. Dengan demikian, pembelajaran matematika adalah membangun pemahaman peserta didik. Terdapat beberapa faktor yang mempengaruhi pembelajaran matematika diantaranya adalah (1) Kegagalan atau keberhasilan belajar tergantung kepada siswa yang dipengaruhi oleh kompetensi, sikap dan minat, kesehatan jasmani dan keadaan psikologis, serta intelegensi. (2) Kompetensi guru dalam menjelaskan materi pembelajaran matematika serta penguasaan terhadap materi. (3) Prasarana yang mendukung seperti ruangan yang sejuk, bersih, dan tempat duduk yang nyaman. (4) Penilaian disamping digunakan untuk melihat bagaimana suatu hasil belajar, juga digunakan untuk melihat bagaimana berlangsungnya interaksi antara guru dan peserta didik (Mustangin, 2002).

Beberapa kompetensi yang harus dimiliki oleh peserta didik diantaranya adalah kemampuan pemecahan masalah dan komunikasi matematis. Pada dasarnya kemampuan pemecahan masalah matematis merupakan satu kompetensi yang penting dan harus dikuasai peserta didik dalam pembelajaran matematika. Hendriana (2017) mengemukakan bahwa pemecahan masalah matematis mencakup model, serta strategi yang merupakan proses inti dan utama dalam kurikulum matematika atau sasaran umum pembelajaran matematika, bahkan sebagai 'jantungnya' matematika. Tidak hanya kemampuan pemecahan masalah matematis, kemampuan komunikasi matematis juga suatu kompetensi dasar yang harus dikuasai oleh peserta didik sekolah jenjang menengah. Beberapa argumentasi yang melandaskan pernyataan berpengaruhnya kemampuan komunikasi matematis bagi peserta didik meliputi; (a) kemampuan komunikasi matematis terdapat dalam kurikulum dan sasaran pembelajaran matematika sekolah menengah, (b) komunikasi matematis merupakan bekal dalam menyelesaikan, dan merupakan wadah dalam beraktivitas sosial dengan temannya, berbagi pemikiran serta penemuan, menilai serta mempertajam ide untuk meyakinkan orang lain, (c) bahkan, kekuatan esensial dalam merumuskan konsep serta strategi matematika adalah komunikasi matematis (Hendriana, 2017). 
Salah satu cara agar dapat meningkatkan kemampuan pemecahan masalah dan komunikasi matematis peserta didik adalah dengan penggunaan model pembelajaran yang baik. Salah satu model pembelajaran yang memfasilitasi peserta didik untuk memiliki kemampuan-kemampuan tersebut adalah model pembelajaran kooperatif. Model pembelajaran kooperatif adalah sinergi yang muncul melalui kerja sama yang akan meningkatkan motivasi jauh lebih besar daripada lingkungan kompetitif individual (Huda, 2013). Model pembelajaran kooperatif yang dinilai mampu meningkatkan kemampuan pemecahan masalah dan komunikasi matematis adalah model pembelajaran kooperatif tipe Student Teams Achievement Division (STAD) dengan alat peraga. Alat peraga adalah suatu alat bantu dalam pembelajaran berupa benda konkret yang dimanipulasi oleh guru dalam proses pembelajaran agar peserta didik lebih memahami materi yang disampaikan. Dengan adanya kolaborasi antara model STAD dengan media alat peraga tersebut, maka tujuan pembelajaran matematika dapat segera tercapai.

Berdasarkan hasil analisis data pretest dan posttest kemampuan pemecahan masalah dan komunikasi matematis peserta didik, dapat diketahui bahwa data kelas eksperimen dan kelas kontrol berdistribusi normal. Sedangkan, berdasarkan hasil uji hipotesis data posttest kemampuan pemecahan masalah dan komunikasi matematis peserta didik, diketahui bahwa $H_{0}$ ditolak untuk uji independent sample $t$ test. Artinya, terdapat perbedaan yang signifikan pada kemampuan pemecahan masalah dan komunikasi matematis antara peserta didik kelas eksperimen dengan peserta didik kelas kontrol. Hal tersebut sejalan dengan penelitian terdahulu yang meneliti pengaruh pembelajaran kooperatif terhadap kemampuan pemecahan masalah matematis yang juga menunjukkan bahwa ada perbedaan yang signifikan pada kemampuan pemecahan masalah di kelas eksperimen dan di kelas kontrol (Zulkarnain, 2015).

Berdasarkan hasil observasi kegiatan pembelajaran, peserta didik telah mengikuti kegiatan pembelajaran di kelas sesuai dengan langkah-langkah kegiatan model pembelajaran yang peneliti gunakan. Sedangkan, catatan lapangan menunjukkan keaktifan peserta didik yang cenderung aktif di kelas eksperimen daripada di kelas kontrol. Pada analisis data kualitatif kemampuan pemecahan masalah dan komunikasi matematis peserta didik melalui hasil wawancara dibedakan dengan 3 kategori, yaitu peserta didik kemampuan tinggi, sedang, rendah. Dalam kegiatan wawancara, peneliti memberikan pertanyaan yang berkaitan dengan hasil posttest yang diperoleh peserta didik sesuai dengan indikator kemampuan pemecahan masalah dan komunikasi matematis. Hal tersebut menunjukkan bahwa hasil wawancara pada kelas eksperimen lebih baik daripada kelas kontrol. Hal ini sejalan dengan penelitian terdahulu yang juga menyatakan hal yang sama yaitu hasil wawancara dari kemampuan pemecahan masalah matematis dan kemampuan komunikasi matematis peserta didik kelas eksperimen jauh lebih baik daripada kelas kontrol (Mahanani, 2016).

Dapat disimpulkan bahwa hasil analisis data kuantitatif dan kualitatif pada model pembelajaran kooperatif tipe STAD berbantuan alat peraga mempengaruhi kemampuan pemecahan masalah dan komunikasi matematis peserta didik kelas eksperimen dengan ditunjukkan adanya perbedaan antara kelas eksperimen yang diberi perlakuan dengan model pembelajaran kooperatif tipe STAD berbantuan alat peraga dan kelas kontrol yang tidak diberi perlakuan dengan model pembelajaran konvensional.

\section{KESIMPULAN DAN SARAN}

Berdasarkan hasil penelitian kemampuan pemecahan masalah dan komunikasi matematis peserta didik kelas VIII SMP Islam karangploso dengan menggunakan model kooperatif tipe STAD berbantuan alat peraga menunjukkan bahwa terdapat perbedaan yang signifikan antara kemampuan pemecahan masalah dan komunikasi matematis peserta didik yang menggunakan model kooperatif tipe STAD berbantuan alat peraga dengan yang menggunakan model konvensional kelas VIII SMP Islam Karangploso. Berdasarkan hasil 
analisis kualitatif, kemampuan pemecahan masalah dan komunikasi matematis antara peserta didik yang menggunakan model kooperatif tipe STAD berbantuan alat peraga dengan model konvensional menunjukkan bahwa, pencapaian indikator subjek kemampuan pemecahan masalah dan komunikasi matematis kategori tinggi, sedang, dan rendah pada kelas eksperimen lebih baik daripada kelas kontrol.

Dari hasil penelitian ini, diharapkan dapat memberikan sumbangan ide-ide dalam upaya meningkatkan kualitas pembelajaran matematika, khususnya dalam meningkatkan kemampuan pemecahan masalah matematis dan kemampuan komunikasi matematis peserta didik. Rekomendasi penelitian selanjutnya adalah perlu adanya penelitian lebih lanjut mengenai langkah kongkrit terkait dengan kegiatan di kelas sebagai bentuk realisasi penelitian ini.

\section{DAFTAR RUJUKAN}

Creswell, J. W. (2016). Research Design Pendekatan Kualitatif, Kuantitatif, dan Campuran. Yogyakarta: Pustaka Pelajar.

Depdiknas. (2006). Standarisasi Sekolah Dasar dan Menengah. Permendiknas No. 22.

Field, A. (2009). Discovering Statistics Using SPSS. California: SAGE Publications Inc.

Hendriana, H., Rohaeti, E. E., \& Sumarmo, U. (2017). Hard Skills dan Soft Skills Matematik Siswa. Bandung: PT Refika Aditama.

Huda, M. (2013). Model-Model Pengajaran dan Pembelajaran. Yogyakarta: Pustaka Pelajar.

Hudojo, H. (2005). Pengembangan Kurikulum dan Pembelajaran Matematika. Malang: Universitas Negeri Malang.

Ismunamto. (2011). Ensiklopedia Matematika. Jakarta: PT Lentera Abadi.

Mahanani, G. (2016). Kemampuan Pemecahan Masalah Matematika Aljabar Berbasis TIMSS Pada Siswa SMP Kelas VIII. Jurnal Pendidikan Matematika. ISSN, 2528-4630.

Moleong, L. J. (2016). Metodologi Penelitian Kualitatif. Bandung: Remaja Rosdakarya.

Mustangin. (2002). Dasar-Dasar Pembelajaran Matematika. Malang: FKIP UNISMA.

Sugiyono. (2014). Metode Penelitian Pendidikan. Bandung: Alfabeta.

Suyono \& Hariyanto. (2011). Belajar dan Pembelajaran. Bandung: PT Remaja Rosdakarya.

Zulkarnain, I. (2015). Pengaruh Model Pembelajaran Kooperatif terhadap Kemampuan Pemecahan Masalah dan Komunikasi Matematika Siswa. Jurnal Formatif. ISSN, 5(1), $42-45$. 